“Transfer” XIV: 1-2 (2019), pp. 202-227. ISSN: 1886-554

\title{
Translating SubJectivity: Hu FenG's Translation of A SOVIET Proletarian Novel
}

Zhen Zhang (ORCID 0000-0001-8006-1310)

University of California, Davis (U.S.A.)

Reception date: 02/02/2018; Acceptance date: 15/03/2018

In the 1920s and 1930s, many Chinese students studied in Japan and formed a variety of literary circles, interest groups, and even magazines. Additionally, some were actively involved in the translation and circulation of texts that were not familiar to Chinese readers. Hu Feng (1902-85) is among these Chinese students. Many $\mathrm{Hu}$ Feng scholars either focus on his inheritance of the May Fourth legacy of critical spirit or his later articulations of "subjective fighting spirit," which leads to his clash with Mao's endorsement of objectivism and his later tragic imprisonment, allegedly for political reasons. However, $\mathrm{Hu}$ Feng's literary activities in Japan are rarely, if ever, studied. Instead of giving a historical account of $\mathrm{Hu}$ Feng's stances and divergences in terms of aesthetics and politics, I look into his literary activities during his years in Japan in general and one case of his translation in particular: the translation of a Soviet proletarianutopian novel titled Mess Mend, or a Yankee in Petrograd (1923) into the Chinese Yanggui (1930) via Japanese translation. I argue that his literary activities in Japan, especially the translation of international proletarian subjectivity revealed in the Soviet proletarian novel, make $\mathrm{Hu}$ Feng a thinker of world proletarian literature, in addition to his other well-known labels such as theorist of May Fourth Movement and theorist of subjectivism. 
“Transfer” XIV: 1-2 (2019), pp. 202-227. ISSN: 1886-554

\section{Beyond the May Fourth Legacy: Hu Feng as a Thinker of World Proletarian Literature}

$\mathrm{Hu}$ Feng, according to the famous literary critic Liu Zaifu, is the "leading theorist of literature in the literary history of modern China" (Liu 2016: 6). ${ }^{1}$ Since his political rehabilitation in the 1980s, many scholarly studies, biographies, memoirs, and even films (Wei and Peng 2009) $)^{2}$ have reflected on Hu Feng the person, his aesthetic theory, and the scandal of "Hu Feng antirevolutionary clique" (Hu Feng fan geming jituan 胡風反革命集團). In English scholarship, three main grounds have been paved in terms of Hu Feng and his contribution to modern Chinese literature. First is the sociohistorical perspective. In his book The Problematic of Self in Modern Chinese Literature: Hu Feng and Lu Ling, Kirk Denton (1998) situates Hu Feng in a broader picture of Chinese literary history and looks into his differences, debates, and literary activities with his contemporaries, and, more specifically, his disciple Lu Ling's literary contribution. Second is a similar sociohistorical approach but with an additional focus on intellectual history and increased emphasis on history of a literary school. In his book Buglers on the Home Front: The Wartime Practice of the Qiyue School, Yunzhong Shu (2000) studies in great detail a leftleaning literary school that emerged out of the literary journal Qiyue 七月 during wartime, for which Hu Feng was the major organizer and contributor. Both studies delineate the external sociohistorical factors that Hu Feng was mired in, and Hu Feng's ideas are played out -if not downplayed - in relation to these external factors. The third pers-

\footnotetext{
${ }^{1}$ The Chinese words he used are "zhongguo xiandai wenxue shi shang de shouxi wenxue lilun jia 中国现 代文学史上的首席文学理论家.”

${ }^{2}$ In the feature documentary film Storm Under the Sun 紅日風暴, the director Louisa Wei revisits the Hu Feng case.
} 
“Transfer” XIV: 1-2 (2019), pp. 202-227. ISSN: 1886-554

pective centers on $\mathrm{Hu}$ Feng's ideas rather than the social and historical surroundings of Hu Feng - that is, the internal aspects of, rather than the external influences on, Hu Feng. Liu Kang belongs to this camp. In his book chapter "Hegemony and Counterhegemony: National Form and 'Subjective Fighting Spirit',"3 Liu Kang (2000) not only examines $\mathrm{Hu}$ Feng's debates, disagreements, and interactions with many other leftist intellectuals in China but also puts Hu Feng's idea of "subjective fighting spirit" in conversation with thinkers outside his immediate circles, including Georg Lukács, Antonio Gramsci, and Mikhail Bakhtin. Here, for Liu, Hu Feng's ideas per se weigh more than his literary associations and activities. In other words, Liu chooses to write a history of Hu Feng's ideas, not another version of literary history of modern China in which Hu Feng plays his part.

My approach to the study of Hu Feng differs from that of the abovementioned three venues. My intent is neither to rewrite a literary history of modern China with a focus on $\mathrm{Hu}$ Feng nor to trace a genealogy of the intellectual history of Hu Feng. Instead, I situate $\mathrm{Hu}$ Feng within global capitalist modernity and look into how $\mathrm{Hu}$ Feng imagines a possible alterity to the hegemonic order in his translation of a Soviet utopian-proletarian novel. Rather than politically reading $\mathrm{Hu}$ Feng's idea of "subjective fighting spirit" and his other articulation of subjectivism as a theory to combat "subjective formulaism" (gongshi zhuyi 公式主義) and “objectivism” (keguan zhuyi 客觀主義), I read his later formulation of subjectivism as a response to, extension, and repetition of this earlier translation, in which we have detected an international proletarian subjectivity. In other words, Hu Feng thinks simultaneously with the vision embedded in the Soviet novel outside

\footnotetext{
${ }^{3}$ This book chapter is a rewriting of his earlier article titled "Aesthetics and Chinese Marxism," Positions 3. 2 (Fall 1995): 597-631.
} 
“Transfer” XIV: 1-2 (2019), pp. 202-227. ISSN: 1886-554

national boundaries, and at the same time he resists a singular version of modernity in his active translation of this world proletarian literature. In what follows I will examine some of the most important episodes of his formative years in Tokyo, Japan. I undertake this task by focusing on two main aspects: first, a brief introduction to $\mathrm{Hu}$ Feng's literary and political activities while he was in Japan; second, a close reading of Hu Feng's translation of "subjectivity" zhuti in the Soviet novel.

\section{Hu Feng in Japan: Proletarian Literature and International Proletarian Solidarity}

Hu Feng lived in Japan between 1929 and 1933, and this period plays an important role in his formation as a thinker of international proletarian resistance and solidarity. In the preface to his first anthology of literary and art critique, titled Wenyibitan 文㙯筆談 (1936), Hu Feng confirmed the importance of his years in Japan in terms of his view on aesthetics. In this confessional piece, we detect a transformation of his aesthetics from a mere ethical reflex (moral didacticism) to a more sophisticated and well-rounded worldview (the life of an intellectual), a philosophy of life. He claims, "Before I met several of my friends in 1931 who enlightened [qimeng 启蒙] and educated me in the field of aesthetic theory, the exchange between art and myself was more or less restricted to the satisfaction of my own desire, finding myself and uplifting myself in the world of art" $(\mathrm{Hu}$ 1999: 2:3). As a result of the year 1931, when he studied in Japan, such a superficial perspective on aesthetics turns into a serious and

necessary matter for real life. He confessed his previous contempt for criticism as a form of writing and thinking: "I despise tremendously 
“Transfer” XIV: 1-2 (2019), pp. 202-227. ISSN: 1886-554

the 'art and literary criticism,' [wenyi piping], ${ }^{4}$ a gesture of criticizing and giving orders to others' fruit of painstaking labor, reinforcing what is good and what is bad, which I believe to be the most despicable [meiyou chuxi 沒有出息] thing” (Hu 1999: 2:3). Later, he denounces this view and appreciates the value of criticism. He claims,

Literary and art criticism should also be for the pursuit of human life [zhuiqiu rensheng], which treads [bashe 跋涉] and explores [tanxun 探 尋] between the world of work of art and real life, and illuminates how a writer, a piece of work, or an artistic phenomenon can give meaning to the mundane life struggle [rensheng douzheng 人生鬥爭]. I have said before that there is no art without human life, and without serving the human life [fuwu rensheng 服務人生] art has no value of existence; similarly, there is no art criticism without human life, and without serving human life, art criticism loses its value. (Hu 1999: 2:4)

As we can see, this latter view of criticism goes beyond the trope of self-fulfillment, ethical reflex, and superficial moralization of aesthetic judgment; it drives towards a view of seeing art and literary criticism as the middle ground between bare life and the art world, which is constantly set into motion, in the rhythm and for the purpose of seeking human life [rensheng]. He uses verbs such as "to seek" [zhuiqiu], "to tread" [bashe], and "to explore" [tanxun] to indicate the "purposiveness" of writing about literature and art, which is supplemented to the purposiveness of human life, or "life struggle" [rensheng douzheng]. And what does he mean when he uses the words human life [rensheng] and life struggle [rensheng douzheng]? The answers to this question will become clear after a close analysis of his literary and political activities in the important years in Japan.

\footnotetext{
${ }^{4}$ For lack of a translatable word, I use "literary and art criticism" as the (mis)translation of wenyi piping.
} 
“Transfer” XIV: 1-2 (2019), pp. 202-227. ISSN: 1886-554

In 1931, Hu Feng was twenty-nine years old, and this was already the second year of his stay in Japan as an international student. To set the clock back a bit, in the fall of 1929 the twentyseven-year-old $\mathrm{Hu}$ Feng, disillusioned with the Chinese revolution, voluntarily went to Japan to further his education and was admitted to the English department at Keio University in Tokyo in the spring of 1931 after unsuccessful attempts to study at Tokyo Imperial University and at Waseda University. ${ }^{5}$ Prior to his formal university education at Keio University, $\mathrm{Hu}$ had seen and personally experienced the Japanese proletariat cultural movement. ${ }^{6}$ For example, when he had just arrived in Tokyo and was still in a Japanese language school, he read many proletarian publications, which deeply moved him for the "genuine emotions and feelings" [zhenqing shigan 真情實感] in the correspondence between the factory workers and peasants, which he believed to be far superior to the works produced within the Creation Society [chuangzao she 創造社], and to contain more humanist passion than Mao Dun's works. ${ }^{7}$ He was so allured by the letters that he even

\footnotetext{
${ }^{5}$ As Hu Feng recounts in his personal memoir, at first he tried to study in a graduate program in Tokyo Imperial University but could not get in due to his unfinished degree in Qinghua University (he only studied in Qinghua for two years before he joined the political struggle in his hometown in Hubei province); he also tried to study Russian in Waseda but was rejected by the dean of literature. He finally got into Keio University thanks to the recommendation of Professor Qian Taosun of Qinghua University (Hu 1993: 5).

${ }^{6}$ In post-2008 Japan there was a resurgence of interest in academia on the topic of the proletarian cultural movement in the 1920s and 1930s. In 2008 The Crab Cannery Ship (Kani kōsen), a major proletarian novella written by Kobayashi Takiji in 1929, surprisingly became a bestseller after longtime neglect by the reading public; 500,000 copies were sold in 2008 as opposed to 5,000 per year previously, and film and manga adaptation ensued. For a detailed discussion of such a cultural movement in Japan in the $1920 \mathrm{~s}$ and 1930s, please see Perry, Recasting Red Culture (Perry 2014: 1-11).

${ }^{7}$ This is the full sentence in which he talks about his alliance with the common people rather than with the artificial ideology endorsed by the Creation Society: "Things written there are either everyday life or struggles of the subalterns, all of which contain genuine emotions and feelings and lured me in. As for the
} 
“Transfer” XIV: 1-2 (2019), pp. 202-227. ISSN: 1886-554

translated them into Chinese and used them to teach Chinese in a local Communism-leaning school.

In addition, Hu Feng became acquaintanced with many important Japanese proletarian writers, such as Ujaku Akita (1883-1962), Takiji Kobayashi (1903-33), Fujieda Takeo (1903-85), and Ikeda Hisao (1906-44). Despite the fact that these acquaintances and friendships were relatively limited and short (Hu 1993: 4), ${ }^{8}$ the radical ideas disseminated during their conversations and discussions took root in the mind of Hu Feng. When he came back to Shanghai, he commented on the death of Takiji Kobayashi and the political struggle of Ikeda Hisao in two poems he wrote in 1950. In "The Beginning of Time" (Shijian kaishi le) and "Album of Heroes" (Yingxiong pu), poems $\mathrm{Hu}$ Feng wrote after the communists won the civil war, he enthusiastically sings the praises of the heroic deeds and laments the tragic deaths of Takiji Kobayashi and Ikeda Hisao. The gesture of mourning for his Japanese comrades further showcases Hu Feng's unwavering positionality within an internationalist, as opposed to nationalist, struggle against hegemony.

In addition to his exposure to Japanese proletarian culture, the poetic self-fashioning and realpolitik Hu Feng experienced in Japan showcase his internationalist stance of proletarian resistance against hegemony. Let us shift back to 1931, the year of the notorious Manchurian Incident (Incident of September 18th), the starting point

works created by the Creation Society I read in China, almost all of them are abstract and empty 'ideological' performances and have no feeling of the common people; Mao Dun's works have concrete descriptions but the images created are bland and dull [lengdan de 冷淡的]: perhaps certain provocative sexual elements are added but there are no life of the genuine emotions and feelings of the common people [putong renmin de zhenqing shigan de shenghuo 普通人民的真情實感的生活]” (Hu 1993: 1).

${ }^{8}$ According to his memoir, Hu Feng met with these figures only on limited occasions, mostly at home gatherings. 
“Transfer” XIV: 1-2 (2019), pp. 202-227. ISSN: 1886-554

of Japan's invasion and further occupation of Manchuria. In this year, $\mathrm{Hu}$ Feng officially started his college studies at Keio University. It should come as no surprise that, as an international student from China and as someone who had experienced political struggles in rural China, Hu Feng could not curb his political activism on this new platform, the highly politicized Keio campus. His long-awaited passion for change along with his newly kindled patriotism pushed him further into the radical student groups at the university. Around this time, as $\mathrm{Hu}$ Feng later recalled, "several extremely important things happened in my life" (Hu 1993: 8). From the poems Hu Feng wrote and the political activities he was involved in during this period, we have a glimpse of these "extremely important things," all of which point to a critique of nationalism and pursuit of internationalist proletarian solidarity.

It started with an enthusiastic poem that he wrote shortly after the Manchurian Incident. In his poem "Sacrifices of the Hated Enemy" (choudi de jili 仇敵的祭禮), Hu Feng describes the Japanese invasion of Manchuria as an act that is mobilized by senseless Japanese nationalism. He criticizes the ritualistic nature of nationalism:

"For the country"-

they create this jugglery by thousands of lies.

"For the country"-

they sanctify this resentful bloodshed by thousands of lies.

In front of ashes of senseless death,

they use "ministers" "generals" ... dignity as the "last salute":

This is a second rape of the deceased,

This is temptation and intimidation of the alive. (Hu 1999: 1:49)

Nationalism is based on lies. Death is honored through rituals in which participants feel tempted and intimidated at the same time. As a Chinese student in Japan, Hu Feng was not a Chinese nationalist 
“Transfer” XIV: 1-2 (2019), pp. 202-227. ISSN: 1886-554

per se. He understood that the Japanese soldiers, too, were being manipulated into their belief in the nonexistent, imaginary "country":

"Brave our military"

the military's "sons" are not commanders themselves!

From the countryside,

from the factory,

from front and end of the streets,

you bring "Yamoto-damashii" and the patriotic heart,

and promote that "country" in which they teach to believe,

From the countryside,

from the factory,

from front and end of the streets,

you bring poverty and oppression,

and all the cruel memories of being fooled and fettered.

You will understand at the very end:

The power of the military,

planes, canons, machine guns, gas...

none of those belong to you,

they are handed to you temporarily

to slaughter brothers that are same as you on the other side of the

shore,

to conquer the territory for them, to build a new throne for them. (Hu 1999: 1:50-51)

This stanza showcases the family background of the military personnel. The soldiers are the subalterns of the Japanese nation: the rural poor, the urban downtrodden, and cheap labor from the industrial sectors. In a tone of camaraderie, Hu Feng addresses these soldiers as equally oppressed human beings, social counterparts of their Chinese opponents, figured here as "brothers." The poem works as a critique of nationalist propaganda as the mobilizing ideology in war: soldiers need to know the beguiling nature of nationalism to 
“Transfer” XIV: 1-2 (2019), pp. 202-227. ISSN: 1886-554

understand that they are mere tokens of war, subject to disposal. Hu Feng is being pedagogical here: the soldiers need to restructure their own minds, which pertains to nationalistic ideological violence, and see the nature of war - their brothers are not the king they are fighting for but the Chinese people of the same origin. What $\mathrm{Hu}$ Feng has in mind is international proletarian solidarity, rather than senseless and narrow nationalism. Furthermore, Hu Feng looks for a transcendence of human beings:

That will be the new humankind's poetry of birth, we brothers ourselves coauthor-

Rise, slaves on this seaside!

Rise, slaves on the other seaside!

Rise, slaves of the world!

Get rid of the chains and fetters on your head, fight for our free and equal "country,"

its name is "earth." (Hu 1999: 1:53-54)

The last sentence breaks away from the confines of anthropocentrism. The Chinese word dadi 大地 has the literal meaning of the vast land and an allegorical meaning of a place of cohabitation, not only for human beings but for all creatures in a given space. $\mathrm{Hu}$ Feng displaces the contradictions of Japanese and others, masters and slaves, commanders and subalterns, etc. with dadi, a utopia yet to be developed.

Along with his poetic fervor, Hu Feng was more and more involved with the realpolitik of Japanese underground leftist politics. His previous literary encounters with proletarian cultural figures were transformed into organized political alliances. Firstly, Hu Feng joined the Research Association of Aesthetics (Yishuxue yanjiuhui 藝術學研究 會), a suborganization of the Institute of Proletariat Science (Puluo 
“Transfer” XIV: 1-2 (2019), pp. 202-227. ISSN: 1886-554

kexue yanjiusuo 普羅科學研究所), which was under the Union of Japanese Proletarian Cultural Organizations. ${ }^{9}$ This group of people met once a week and discussed aesthetic theory, the international labor movement, and the philosophy of dialectics ( $\mathrm{Hu}$ 1993: 8). $\mathrm{Hu}$ Feng published articles on the topic of Chinese antiwar literature and translated some of the writers from this group in the group's journal Studies in Aesthetics (Yishuxue yanjiu 藝術學研究). The other group that Hu Feng actively participated was called Antiwar Allies (Fanzhan tongmeng 反戰同盟) and was led by the Japanese Communist Party; Hu Feng, along with Fang Han and Wang Chengzhi, formed a Chinese reading group of the party journal Red Flag (Chiqi bao 赤旗報), who were later accepted as official members of the Japanese Communist Party. This was a group based on reading and writing. There were three main tasks of the group: first, they read Red Flag regularly; second, they formed a study group called Study of Emergent Culture; third, they started a samizdat-journal called Emergent Culture (Xinxing wenhua 新興文化) ( $\mathrm{Hu}$ 1993: 10). Before long $\mathrm{Hu}$ was dispatched to Shanghai as an agent to build connections for the organization, where he met Zhou Yang (1908-89), Feng Xuefeng (1903-76), and Ding Ling (1904-86), who were the leading figures of the League of Left-Wing Writers. In addition to the two groups Hu Feng joined in Japan, he also took part in the Tokyo branch of the Chinese League of Left-Wing Writers (zuolian 左聯).

The realpolitik that $\mathrm{Hu}$ Feng was mired in brought about his imprisonment and deportation. He was arrested and badly beaten in Tokyo and deported to Shanghai in 1933. When he returned to Shanghai, Hu Feng was no longer a college student in Japan, but carried with himself the aura of a political activist who had the

${ }^{9}$ 本プロレタリア文化連盟 
“Transfer” XIV: 1-2 (2019), pp. 202-227. ISSN: 1886-554

audacity to fight against the Japanese military power in its native soil and found his way to build coalitions with local Japanese sympathizers of China under occupation.

The Japanese period opened up a whole world that would continue to inform Hu Feng's strong stance on internationalism rather than unchecked nationalism. In this sense, Hu Feng was not only an inheritor of the May Fourth enlightenment and intellectualism that many scholars would immediately associate him with, but also, more personally and experientially, an equal contributor to the Japanese leftists' resistance against Japanese nationalist militarism. The Chinese identity Hu Feng held while in Japan imposed a distance between him and the Japanese circle of the left-wing intellectuals and at the same gave him sober insight into the beguiling nature of nationalism and war because of his intimate contact with Japanese subalterns. The internationalist stance for him was not simply a slogan but a rational and clear-headed practice generated from his observation, learning, and political engagement.

In his poetic self-fashioning and realpolitik we have a glimpse, if not a view of all aspects, of Hu Feng as a thinker. In the globalized world $\mathrm{Hu}$ Feng identified, he managed to see the deep connections, the hidden traces of globality in the 1930s. He conceived an alterity that was still not quite clear to him and to the globe.

Hu Feng's Translation of International Proletarian Subjectivity Besides avid reading and political experience, during this period $\mathrm{Hu}$ Feng translated a Soviet novel into Chinese via the recent Japanese translation. The novel $\mathrm{Hu}$ Feng (under the nom de plume $\mathrm{Gu}$ Fei) translated is Mariètta Shaginian's Mess-Mend: Yankees in Petrograd Месc-Менд, или Янки в Петрограде (1923) with a subtitle roman-skazka роман-сказка, meaning literally "novel-fantastic tale.” Hu Feng's Chinese translation titled Yanggui 洋鬼 (Foreign Ghosts) (1930) was based on 
“Transfer” XIV: 1-2 (2019), pp. 202-227. ISSN: 1886-554

the Japanese translation, which was translated from the original Russian by Hirokichi Otake $^{10}(1890-1958)$ in 1929-30. It is a "red fantasy" (Hu 1993: 2) ${ }^{11}$ that tells a story about a group of New York working-class (communist) revolutionaries who sneak into the early Soviet state and help their Russian comrades crush the ongoing American espionage by the ruling social class in New York. ${ }^{12}$ In this translated novel, Hu Feng conceives an international proletarian subjectivity that is registered through an "epistemic change," a shift from intellectual elites to the working class as the source of knowledge.

Through working on his translation of this novel, Hu Feng first encounters and considers the key term subjectivity-in Chinese, zhuti 主體. This is probably the first time the currently influential academic term zhuti is used and discussed in the context of literature and aesthetics, but this is definitely the first time in Hu Feng's writing. As later you will see, zhuti as a translated term needs to be contested. In the first publication of the translation by Kunlun Bookstore (kunlun shudian 崑崙書店) in Shanghai, Hu Feng wrote the following paragraph as the postscript, in which he implicitly calls for an epistemic change of "us," as intellectuals, writers, readers, and translators, from cul-

${ }^{10}$ Hirokichi Otake 大竹博吉 was very active in the Japanese proletarian cultural scene. His Russian was excellent, and he had a bookstore that sold mostly Marxist-Leninist works in translation and even published a journal called Proletarian Literature, according to the memoir of Hu Feng.

${ }^{11}$ The Chinese is “hongse de huanxiang zuopin 紅色的幻想作品”.

${ }^{12}$ Such a theme concerning Americans' journey to the Soviet Union is not uncommon in the Soviet Union in the 1920s. The most memorable piece of artwork from this period is Extraordinary Adventures of Mr. West in the Land of the Bolsheviks (Neobychainye priklyucheniya mistera Vesta v strane bolshevikov Необычайные приключения мистера Веста в стране большевиков) (1924), by Lev Kuleshov (18991970), which depicts an American, Mr. West, who travels to Moscow with prejudice against the Soviet Union; the prejudice is dissolved after his time in the newly founded state, and he starts to like the new state more and more. 
“Transfer” XIV: 1-2 (2019), pp. 202-227. ISSN: 1886-554

tural elitism to the immediate, everyday life, including a linguistic reformulation of writing, which should be generated from the working people:

The author says in "Prelude" that "the novel we want is something like this-it is a work that makes us feel that we ourselves are the subjectivity [italics added] of life" [shi nenggou shi women ba ziji shi shenghuo zhuti zhehuishi gandao de zuopin 是能夠使我們把自己是生活 主體這回事感到的作品]. This sentence is quite thought provoking for those of us who have "cultivation of art” [yishu xiuyang 藝術修養] and who have received "high and sophisticated education" [gaoshen jiaoyu 高深教育]. Thus, I have thought before that if one can translate this work using the colloquial language of the workers in the society [gongren shehui de suyu 工人社會的俗語], it would probably be more meaningful. (Hu 1999: 8: 314)

In Hu Feng's translation, zhuti 主體 is used to indicate the transformation of intellectual labor from the cultural elites to the working people. Since the word zhuti has found its way into many aspects of academic discourses nowadays-referring both to a political subjectivity as well as a cultural and philosophical one-it is necessary to clarify the meaning when $\mathrm{Hu}$ Feng translates it. While $\mathrm{Hu}$ Feng translates from the Japanese, he copies the Japanese kanji 主體. ${ }^{13}$ The Russian original on which the Japanese translation is based uses the word khaziai хазяй ${ }^{14}$ in its plural form, which has the literal

\footnotetext{
${ }^{13}$ The Japanese sentence reads, それは われわれ, 我々に、じぶん，自分が せうせつ

${ }^{14}$ The Russian sentence reads, "Nam podaj takuju literature, shtoby mypochustvovali sebja khazjaevami zhizni нам подавай такую литературу, чтобы мы почувствовали себя хозяевами жизни.” The literal
} 
“Transfer” XIV: 1-2 (2019), pp. 202-227. ISSN: 1886-554

meaning of "host" as in a domestic setting; here it carries a sense of homeliness and familiarity. "Host" also conveys a sense of ownership, but it refers to a precapitalist sense of ownership (the word is often used in a gendered and combined word, domakhaziaika домахазяйка, meaning a woman who is good at taking care of the domestic space, including household chores, husband, children, and relatives), which points less to the ownership of private property than to the sense of confidence in knowing how to deal with practical matters.

This paragraph was written after his translation of the whole novel. Hu Feng knows intimately the intricate meaning of the signified when he uses the word zhuti. Shortly after his statement emphasizing the purpose of the novel, Hu Feng is being satirical, using phrases such as "cultivation of art" and "high and sophisticated education," warning against the isolation and provincialism of the cultural elites and their unquestioned distance from the common people, from life itself. Along with the novel, Hu Feng envisions a change in the perception of knowledge - the common working people should also have access to the intellectual labor of so-called educated elites. It is my task to show how this novel orchestrates an epistemic change towards a new subjectivity of the proletarian as the host-master, not a guest-slave, of the society. In what follows I examine the fictional author, structure, and storyline of the novel, all of which point to a reconfiguration of subjectivity, that is, a proletarian-subjectivity.

The authorship of the novel is intentionally obscured, a gesture that defies the conventional form of the bourgeois novel, in which authorizing the text with the writer's name is the norm. Prior to the main body of the story itself, we have two fictional readercommentators who bear witness to the story through preliminary

translation would be, "We should be given the kind of literature that we feel ourselves to be the host" (Shaginian 1971: 242). 
“Transfer” XIV: 1-2 (2019), pp. 202-227. ISSN: 1886-554

paratexts. The one appearing first in the text is titled "Prologue." From this short commentary we know that the fictional author Jim Dollar is an American worker, familiar with neither Russia nor Russian; he makes "magical mistakes" in terms of Russian names. ${ }^{15}$ The implication is that Jim Dollar's text is not reliable, not accurate, and probably full of "magical mistakes," in other accounts as well, but the point is that "these magical mistakes are the elements of the origin of the novel" (Hu 1999: 8:11). In the other piece inserted prior to the story, "The Background of Jim Dollar" [Jimu Duoer de laili], we know the biography of Jim Dollar from M. Sh., ${ }^{16}$ which suspends the trustworthiness of the text, leaving it to the readers to judge. These two layers obscuring the author, mistake-ridden Jim and the unconvincing biography of Jim, jointly destabilize the bourgeois subjectivity of the author-figure.

Not only do we see the intentional destruction of the authorsubject, but we also see the construction of a unique proletarian author in the figure of Jim Dollar. In the piece titled "Background of Jim Dollar” (Jimu Duoer de laili 吉姆朵爾的來歷), listed prior to the main body of the text, the life story of the fictional author unfolds. The created fictional author is the orphan Jim Dollar, who was born in New York, raised by a porter, and who spends most of his life on the

${ }^{15}$ The “magical mistakes" are qimiao de cuochu 奇妙的錯處 in Chinese. These mistakes include translating "moika river," meaning "to clean-river" in Russian, to "buria," meaning "storm"; and "shining eyes of Lenin" - but Lenin's eyes cannot "shine." Here Jim Dollar's translation-as-mistake of Russian names is magical in the sense that common Russian words are defamiliarized and new meanings are created. We see that the mistranslation, invoking the metaphor of storm, serves the purpose of the novel particularly well—a novel for the revolutionary mass. See Hu (1999: 8:11). "Zhexie qimiao de cuochu, yuanshi xiaoshuo de faduan yaosu zhiyi ne 這些奇妙的錯處原是小說的發端要素之一呢.”

${ }^{16}$ In the Russian original, the signature of the piece is M. Sh., indicating the real author of the novel, Mariètta Shaginian. In Hu Feng's translation, the name is transliterated as yemu xi'e 葉母·希厄, which further estranges the author of this paratext. 
“Transfer” XIV: 1-2 (2019), pp. 202-227. ISSN: 1886-554

street, experiencing all kinds of mistreatment and humiliation. The hegemonic knowledge that surrounds him is not a source of empowerment but a source of oppression and exclusion. He is tricked into working as child labor, almost trapped as a sex slave by a woman because of his lack of legal knowledge when she purchases him along with a bunch of boxes. The epistemic damage inflicted on Jim deprives him of any access to established knowledge. In other words, Jim has never been institutionalized, or properly educated, as many writers would have been. However, this epistemic damage does not necessarily weaken his will, but rather endows him with an unexpected restructuring of knowledge that ultimately breaks away from hegemony and order. Jim's educational experience, that is, epistemic formulation, comes from two venues: cinema and strike:

After lingering around the factory street in New York for a long time, he finally finds a job in the match factory-he becomes a worker. Two incidents provoked his feelings: his first time on strike and the first time he watches a film. Judging from his later works, the strike teaches him "the means through which one can resist enemies and defend oneself." And cinema is "a metropolis novel that has the most fans in the modern world." (Hu 1999: 8:15)

These two sources of knowledge, strike and cinema, make Jim an epistemically different subject from the bourgeois subject; Jim is both conscious of social justice and the masses.

Furthermore, the novel is structured so that proletarian subjectivity is at the center of the readers' attention, and such a subjectivity has the power to secretly sabotage the everyday social order. Apart from the "Prologue" (уuаnхи 原序) and the "Background of Jim Dollar," (Jimu Duoer de laili 吉姆朵爾的來歷), within Jim Dollar's text we encounter a "Prelude" (хиqu 序曲) that includes several heterogeneous and fragmented speeches by a union leader, Michael, from 
“Transfer” XIV: 1-2 (2019), pp. 202-227. ISSN: 1886-554

Middletown; an "Epilogue" (weisheng 尾聲) that resumes the working day as if nothing happens ( $\mathrm{Hu}$ 1999: 8:312): ${ }^{17}$ and ten titled chapters inserted in between the two paratexts. The inserted text recounts the fantasy about the collective efforts of New York industrial workers and Soviet proletariats to bring down the anti-Soviet sabotage of the New York ruling elite. Here the text represents the hidden reality, the unseen, the underground, the surreptitious connection, and the collective power of the working class, interjected between the prelude and the epilogue, in which we see two contrastive forms of the everyday: the former focuses on the shakeup of the working day by a union leader's inflammatory and rhapsodic speeches, and the latter resumes everyday labor activity in a jocular way, transformed and taken anew, infused with cheerful songs, and echoing the pulsating speeches of the union leader. Something happens in between the two forms of everyday life: readers' desire is redirected to silenced realities, the unspoken unconsciousness, the crossed-out but visible traces - a desire to sabotage the everyday. In sum, the story told by Jim Dollar interrogates the everyday, and substitutes these daily habits imbued with repression and exploitation with a new novelistic discourse. In this sense, the transnational proletarian subjectivity as shown in the content of the novel fosters a critique of the received ideology of the working day. This inserted text reinforces neither a picket-line strike nor organized unionism. Instead, desires are

\footnotetext{
${ }^{17} \mathrm{Hu}$, Quan ji, 8:312. The epilogue begins with this sentence: "In Middletown's factory, nothing seems to have happened [sihu shenme shiqing ye meiyou fasheng yiyang 似乎什麼事情也沒有發生一樣]. Works continue as usual."
} 
“Transfer” XIV: 1-2 (2019), pp. 202-227. ISSN: 1886-554

directed to "secrets" (Hu 1999: 8: 313) ${ }^{18}$ things that cannot be spoken. The secret is played out in the main body of the text.

The proletarian subjectivity in the novel's main body expresses itself through a somewhat phantasmagorical vision of a Soviet proletarian utopia in which the capitalist elites in New York are successfully converted to socialism and the proletariat become the masters of the production process, in an organic integration of hands and minds. The story has many layers of construction. First of all, it is a story of personal revenge: the rumor goes that Rockefeller Jr.'s banker father was murdered by communists, which drives him to take vengeance on the communists in the Soviet Union; on the other side of the coin, Miss Vivian Orton's mother has a relationship with Rockefeller the father and she is mysteriously murdered (eating a poisoned pear) shortly before their scheduled marriage, and Miss Vivian Orton blames Rockefeller for the murder of her mother $\mathrm{Hu}$ 1999: 8:86). Miss Orton's revenge is directed at Rockefeller Jr. when she finds out that someone else has murdered the father. Second, the personal revenge is absorbed into a larger picture of struggle: a class struggle. Their vengeful desires are appropriated by two confrontational forces, namely, the New York working class (New York sympathizers of the Soviet state) and the international coalition of aristocratic classes lead by a mysterious figure named Chiche (head of the central committee of fascists) (Hu 1999: 8:99). The latter takes advantage of Rockefeller Jr.'s personal hatred of communists and uses him as a spy to bomb Soviet industrial infrastructure; the former finds a way to substitute Miss Orton's vengeful desire with the much bigger struggle of the freedom of mankind (Hu 1999: 8: 89). Third, the

${ }^{18}$ And the union leader blames Jim for disclosing their secrets ( $m i m i$ 秘密) in the novel: "You make the story too obvious [tai lougu le 太露骨了]. Those young people will be grouchy about this. You [Jim] are disclosing our secrets too early." 
“Transfer” XIV: 1-2 (2019), pp. 202-227. ISSN: 1886-554

class struggle escalates into a pre-Cold War competition of mutual infiltration of spies, a story of sabotage and antisabotage, an invisible combat between the socialist Soviet state and the capitalist US. Rockefeller Jr. disguises himself as an American communist party member, Vasilov, and infiltrates the early Soviet state as a spy. His purpose as a spy is to "bomb the Russian steel plant and bomb all the industries in Russia" (Hu 1999: 8:166). Miss Orton, on the contrary, is dressed up as the real Vasilov's wife (Mrs. Vasilova) and planted on the same ship to the Soviet Union. Instead of carrying out the sabotage plan, Rockefeller Jr., a former misogynist, not only falls in love with Miss Orton, but also converts himself to the Soviet causehe decides to denounce his family lineage and stay in the Soviet Union for the rest of his life (Hu 1999: 8:308). ${ }^{19}$ The end of the story falls to the line of unproblematized propaganda: Rockefeller the father is as a matter of fact alive, and the murderer is no other than Elizabeth, his self-proclaimed wife, who has never been his wife but the wife of Duke Chiche (Hu 1999: 8:307) ${ }^{20}$ The mutual espionage ends with the success on the Soviet side. The takeaway of the novel is as propagandistic as it is entertaining: the Soviet ideology wins over the young generation of Americans without any bloodshed.

While novel does display the somewhat unsophisticated propaganda of early Soviet proletariat internationalism, it nevertheless projects a vision of proletariat subjectivity, an integration of manual labor and intellectual labor, of production and creation, of specialty and generality. This utopian vision is projected into the

19 "You are the son of the biggest factory of America. And you became an accomplice of our enemy [women diren de tongdang 我們敵人的同黨]!”

20 "That woman has never been my wife. Artur, she is an evil woman-she is the one who murdered Vivian's mother and the accomplice who wants to murder me and you too! She is the wife of Duke Chiche!" 
“Transfer” XIV: 1-2 (2019), pp. 202-227. ISSN: 1886-554

chronotope of the early Soviet Union. The following conversation occurs when Rockefeller Jr., dressed as the American communist leader Vasilov, arrives in the Soviet Union and meets with local workers. What he is about to witness and hear structurally displaces his longstanding perception of labor, production, happiness, and, most importantly, the construction of knowledge. Amid his exchanges with the Soviet workers, Rockefeller conceives of an alternative pathway to knowledge. Power does not come from the capture of the machine, the tools, and other means of production; rather, power lies within the knowledge of the machine, the tools, and the means of production.

"Look at those people," Enno says, "they glow with happiness. We made the biggest revolution since history began. But, if we do not march forward after the revolution, that is bullshit. We snatched the means of production [italics added; shengchan jineng zhengduo daoshou 生產技能爭奪到手]. We strive for the happiness of mankind.”

"That is mere utopia!" Vasilov murmurs as if making a sigh. "You are right," Enno immediately catches the end of that sentence, and says, "We've always been working to actualize utopia as our own task. The best brains among us spend a lot of time and energy to do this; there are only two things that give people happiness-to create [chuangzao 創造] and to know [renshi 認識]. But, up to now the ones who create understands nothing; they know nothing about "to know". But the ones who know cannot create [italics added; congshi chuangzao de ren duiqi shenme dou budong, meiyou jiaozuo "renshi" de dongxi. er you renshi de ren you shenme dou buneng chuangzao 從 事創造的人對其什麼都不懂，沒有叫做 “認識” 的東西。而有認識的人又什麼 都不能創造]. Up to now we have the monstrous, crippled, incomplete mongrel - the mutual relations between the full-of-nonsense professors and workers of automatic machinery; this should be permanently linked up and cannot be otherwise. We have once and for all decided: we should produce with knowledge and know along 
“Transfer” XIV: 1-2 (2019), pp. 202-227. ISSN: 1886-554

with production. But how to achieve this? So, comrades, the so-called singular economic method [italics added; danyi de jingji fangfa 單一的 經濟方法] gives us tremendous help for sure. That's right. When we reached extreme poverty, the very end of destruction, and when we were mired in hunger, when there was no production and no market, on one hand we endured in in such an economic state, and on the other hand we studied singular economic method. We even planted potatoes in drawers. We made leather to make leather shoes; we washed and dyed old tulle. Mining, agriculture, manufacture: you name it-we did it. So, from the intellectuals from the metropolis to the rural peasants, the economic organization, that is, the interrelations of production, pieces together one after another and forms into one [italics added; lianjie cheng le yige 連結成了一個]. Our socalled "singular economic method" [jingji danyi fa 經濟單一法] ${ }^{21}$ is something like this. It is this after all: among workers of our country, nobody -without knowing the total interlocking relations of production- conducts his own work. For example, he makes thumbtacks; but while he makes this, on the one hand, he not only knows the mining of minerals but also knows the optical splitter of that mineral; on the other hand, he knows how thumbtacks are going to be useful for more complicated products, such as furniture and spiral phase plates of microscopes, etc. In other words, that is, we treat our production like the organization of an orchestra [italics added; yinyuedui de zuzhi 音樂隊的組織]. From the drummer to the violin player-each one is not only in charge of one's own notes, one also has to listen to the total symphony. One has to understand that and has to manage his own business, understand?." (Hu 1999: 8:19394)

\footnotetext{
21 The Russian original for this economic method is "eginyi metod khoziaistva единый метод хозяйства." It is interesting to notice that khoziaistva хозяйства, meaning economics, and the purpose of the novel khoziain хозяин in "subjectivity of our life" have the same stem.
} 
“Transfer” XIV: 1-2 (2019), pp. 202-227. ISSN: 1886-554

Enno's argument contains two main points. First, the proletariat should not just be the mere producers of commodities who take orders from others, but intellectuals who know the relations of production well enough to create. In other words, the piano makers should be the piano players. On the one hand, we have older institutionalized knowledge, which is still producing and reproducing itself through institutions and discourses; on the other hand, we have knowledge that is constantly being generated from the production sectors. The contradiction between the former and the latter is deeply imbedded in knowledge production. The utopian vision emphasizes renshi, to know in a process. Second, the proletariat is aware of the totality of knowledge. This is not to say there should not be specialized knowledge. On the contrary, this utopian vision construes an alternative view of the division of labor, rather than eradicating it. The division of labor is appropriated: one has expert knowledge of a single unit of production; at the same time, one has an understanding of the totality. One is not locked into one's discipline, specialty, jargon, department, etc. without discomfort; one belongs to a discipline, specialty, jargon, department, only on the condition that one is aware of the totality, the whole. One is singular but one desires the whole. Self-synecdochtizing is the unwritten text in this imagined "singular economic method." The metaphor given by Enno aptly illustrates this new subjectivity: everyone in the "orchestra" works for the whole, yet everyone has his or her own notes to play. Polyphony, as it were, is created in production. In the polyphonic utopia, labor power is the commonality of every member of the society and useful labor is the singular musical phrase specific to one's purpose. It is an interdisciplinarity with a totality as the background, a cross-pollination of knowledge with a common denominator.

In this article I offer a new approach to the study of Hu Feng. As opposed to the common notions of Hu Feng as either inheriting 
“Transfer” XIV: 1-2 (2019), pp. 202-227. ISSN: 1886-554

the May Fourth legacy or being a tragic victim of political persecution, I situate $\mathrm{Hu}$ Feng in the context of world proletarian literature by looking into Hu Feng's literary and political activities, as well as his translation of a Soviet proletarian novel during his years in Japan. Through these activities, I argue, Hu Feng conceives of an international proletarian subjectivity as an alterity of global capitalism, one that not only transcends nationalist mythology, but also imagines a possibility of the proletariat as the master of production, knowledge, and life itself.

\section{WORKS CITED}

DENTON A. Kirk. (1998). The Problematic of Self in Modern Chinese Literature: Hu Feng and Lu Ling. Stanford, CA: Stanford University Press.

DORU, Jimu. (1928). ジム・ドル. Mesu Mendo メス・メンド [Mess Mend]. Translated by Takeshi Hiroo 廣尾猛. Tokyo: Sekai Sha 世界社.

HU, Feng. (1993). Hu Feng hui yi lu. Beijing, China: Renmin wenxue chubanshe.

---. (1999). Hu Feng quan ji. 10 vols. Wuhan, China: Hubei renmin chubanshe.

LIU, Jianmei. (2016). "Liu Zaifu Fangtan Lu.” Huawen Wenxue, 6: 5-9.

LIU, Kang. (2000). "Hegemony and Counterhegemony: National Form and 'Subjective Fighting Spirit."' In: Aesthetics and Marxism: Chinese Aesthetic Marxists and Their Contemporaries, pp. 72110. Durham, NC: Duke University Press.

PERRY, Samuel. (2014). Recasting Red Culture in Proletarian Japan, Childhood, Korea, and the Historical Avant-Garde. Honolulu, Hawaii: University of Hawaii Press. 
“Transfer” XIV: 1-2 (2019), pp. 202-227. ISSN: 1886-554

SHAGINIAN, Mariètta Sergeevna. (1971). Mess-mend, ili Janki $v$ Petrograde. In: Sobranie sochinenii deviati tomakh, Vol. 2. Moscow: Khudozh. lit-ra, pp. 233-494.

SHU, Yunzhong. (2000). Buglers on the Home Front: The Wartime Practice of the Qiyue School. Albany: State University of New York Press.

WEI, S. Louisa and Xiaolian PENG (2009). Hong ri feng bao [Storm under the Sun]. Hong Kong: Blue Queen Cultural Communication.

\begin{abstract}
:
The renowned Chinese intellectual Hu Feng (1902-1985) is either referenced as the heir of the May Fourth critical spirit, especially that of Lu Xun (1881-1936), or associated with a famous case of political persecution in the 1940s and 1950s, namely, the "Hu Feng AntiRevolutionary Clique." However, the young Hu Feng as a translator during his years in Japan is somewhat neglected. This article situates $\mathrm{Hu}$ Feng in the context of world proletarian literature. I look into $\mathrm{Hu}$ Feng's literary activities in Japan and examine his Chinese translation, Yanggui (1930), of a Soviet proletarian-utopian novel titled Mess Mend, or a Yankee in Petrograd (1923) via Japanese translation. I argue that the years in Japan and his translation of the Soviet novel shape Hu Feng as a thinker of international proletarian subjectivity.
\end{abstract}

\title{
Key Words:
}

Hu Feng, Translation, Proletarian literature, Subjectivity, Soviet novel 
“Transfer” XIV: 1-2 (2019), pp. 202-227. ISSN: 1886-554

TRADUCIENDO LA SUBJETIVIDAD: LA TRADUCCIÓN DE HU FENG DE UNA NOVELA PROLETARIA SOVIÉTICA

\section{Resumen:}

Al renombrado intelectual chino Hu Feng (1902-1985) se le menciona ya sea como el heredero del espíritu crítico del 4 de mayo, especialmente el de Lu Xun (1881-1936), o como el asociado con un famoso caso de persecución política en los años 1940 y 1950, es decir, la "Camarilla anti-revolucionaria de Hu Feng". Sin embargo, la labor del joven $\mathrm{Hu}$ Feng como traductor durante sus años en Japón está algo descuidada. Este artículo sitúa a Hu Feng en el contexto de la literatura proletaria mundial. En él se estudian las actividades literarias de Hu Feng en Japón y se analiza su traducción china, Yanggui (1930), de una novela soviética proletaria-utópica titulada Mess Mend, o un yanqui en Petrogrado (1923) mediada a través de una traducción al japonés. En este artículo argumento que los años en Japón y su traducción de la novela soviética conforman a Hu Feng como un pensador de la subjetividad proletaria internacional.

Palabras clave:

$\mathrm{Hu}$ Feng, Traducción, Literatura proletaria, Subjetividad, Novela soviética 